Jurnal Widya Laksana, Vol.11, No.1, Januari 2022

\title{
PENINGKATAN REGULASI EMOSI MELALUI PROGRAM HARMONY FROM WITHIN PADA REMAJA PANTI ASUHAN NARAYAN SEVA BULELENG-BALI
}

\section{Dewa Ayu Puteri Handayani ${ }^{1}$, Dewa Bagus Sanjaya ${ }^{2}$, Nice Maylani Asril ${ }^{3}$, I Putu Mas Dewantara ${ }^{4}$}

\author{
1,3Prodi Pendidikan Guru Pendidikan Anak Usia Dini, Universitas Pendidikan Ganesha \\ ${ }^{2}$ Prodi Pendidikan Pancasila dan Kewarganegaraan, Universitas Pendidikan Ganesha \\ ${ }^{4}$ Prodi Pendidikan Bahasa Indonesia, Universitas Pendidikan Ganesha
}

email: ayu.puteri@undiksha.ac.id

\begin{abstract}
Abstrak
Kegiatan pelatihan dan pendampingan psikologis dengan judul Harmony from Within bertujuan untuk meningkatkan regulasi emosi remaja di Panti Asuhan Narayan Seva, Buleleng-Bali. Masyarakat sasaran berjumlah 22 orang berusia 16 hingga 20 tahun. Metode yang digunakan adalah seminar, diskusi, presentasi, dan kerja kelompok. Berdasarkan evaluasi yang dilakukan, ditemukan bahwa kegiatan ini dinilai sangat baik oleh peserta. Selain itu, ditemukan pula perbedaan skor regulasi emosi pada dua strategi yaitu strategi merekonstruksi kognitif dan strategi menahan ekspresi emosi sebelum dan setelah pelatihan. Sebanyak $68 \%$ peserta mengalami peningkatan dalam menerapkan strategi rekonstruksi pikiran, dan hanya $27 \%$ peserta yang pada akhirnya mampu meminimalisir penerapan strategi menahan ekspresi emosi. Hal ini menunjukkan bahwa kegiatan pelatihan dan pendampingan ini dapat memberikan manfaat untuk meningkatkan keterampilan merekonstruksi pikiran, namun tidak dalam keterampilan mengekspresikan emosi.
\end{abstract}

Kata kunci: regulasi emosi, rekonstruksi kognitif, ekspresi emosi

\begin{abstract}
The psychological training and mentoring entitled "Harmony from Within" aimed at improving emotion regulation strategies of adolescents at the Narayan Seva Orphanage, Buleleng-Bali. Participants were 22 adolescents ranging from 16 to 20 years old. The methods included seminar, discussion, presentation, and group work. Based on the evaluation conducted, it was found this activity was rated very well by the participants. In addition, there were also differences in emotion regulation scores among the two strategies, namely cognitive reappraisal and the expressive suppression before and after training. As many as $68 \%$ of the participants experienced improvement in implementing cognitive reappraisal strategy, and only $27 \%$ of participants were finally able to minimize the implementation of expressive suppression strategy. These results showed that the training and mentoring given could provide benefits for improving cognitive reappraisal strategy, but not in minimizing expressive suppression strategy.
\end{abstract}

Keywords: emotion regulation, cognitive reappraisal, expressive suppression 


\section{PENDAHULUAN}

Pandemi

Covid-19

mempengaruhi kesehatan mental sebagian besar masyarakat di seluruh dunia, khususnya bagi mereka yang terdampak secara langsung. CNN menyebutkan bahwa isu kesehatan mental menjadi salah satu isu terbesar yang terjadi di tahun 2021 akibat pandemi Covid-19. Upaya vaksinasi yang dilakukan oleh pemerintah diduga dapat menimbulkan rasa lega di kalangan masyarakat, namun pada kenyataannya ketakutan akan terkena virus ini masih menghantui masyarakat, terlebih dengan varian baru yang penyebarannya dinilai lima kali lebih cepat dan masif daripada varian asli (Pranita, 2021).

Dampak dari pandemi ini dirasakan oleh semua orang. Namun demikian, kelompok masyarakat yang memiliki kerentanan psikologis (psychological vulnerability) merasakan dampak yang jauh lebih besar. Kerentanan psikologis mengacu pada struktur kognitif yang membuat seseorang lebih rentan mengalami stress serta bergantung pada pengakuan eksternal untuk mengembangkan keberhargaan diri (Sinclair \& Wallston, 1999). Salah satu kelompok masyarakat dengan kerentanan psikologis adalah anakanak yatim piatu (Killian \& Durrheim, 2008). Anak-anak ini sudah mengalami kehidupan yang cukup sulit bahkan sebelum pandemi, dengan tidak adanya orang tua sebagai support system serta berbagai keterbatasan di Panti Asuhan. Dengan kondisi pandemi seperti saat ini, ruang gerak anak-anak tersebut semakin terbatas, yang mana hal ini dapat mempengaruhi kesehatan mental mereka secara umum.

Kemampuan regulasi emosi menjadi kemampuan yang sangat krusial dimiliki karena keterampilan regulasi emosi yang rendah dapat mengantarkan seseorang pada psikopatologi (McLaughlin, Hatzenbuehler, Mennin, \& NolenHoeksema, 2011). Regulasi emosi mengacu pada proses pembentukan emosi yang dimiliki seseorang, kapan seseorang memilikinya, dan bagaimana seseorang mengalami atau mengekspresikan emosi tersebut (Gross, 1998b). Dengan memiliki kemampuan regulasi emosi yang baik, individu dapat mengurangi intensitas atau durasi emosi negatif, terutama kemarahan, kesedihan, dan kecemasan, dengan fokus khusus pada penurunan pengalaman dan ekspresi emosi negatif (Gross, Richards, \& John, 2006). Selain itu juga dapat meningkatkan intensitas atau durasi emosi positif, terutama cinta, minat, dan kegembiraan, seringkali dengan berbagi pengalaman positif mereka dengan orang lain (Quoidbach, Berry, Hansenne, \& Mikolajczak, 2010). Oleh karena itu, kemampuan regulasi emosi dalam masa pandemi sangat dibutuhkan apalagi di antara remaja Panti Asuhan.

Maka dari itu, permasalahan pengabdian ini difokuskan pada pendampingan psikologis dalam rangka meningkatkan keterampilan regulasi emosi pada remaja di Panti Asuhan Narayan Seva Buleleng melalui program "Harmony from Within". "Harmony from Within" merupakan sebuah program yang dirancang dengan menggunakan dua strategi 
regulasi emosi yang dikemukakan oleh Gross \& John (2003), yaitu antecedentfocused dan response-focused. Antecedent-focused mengacu pada hal-hal yang dilakukan sebelum merasakan kecenderungan emosi tertentu. Strategi yang sesuai dengan fokus ini disebut dengan cognitive reappraisal. Sedangkan responsefocused mengacu pada hal-hal yang dilakukan setelah merasakan emosi. Strategi yang sesuai dengan fokus ini disebut dengan expressive suppression. Cognitive reappraisal adalah strategi merekonstruksi penafsiran terhadap situasi yang dapat memunculkan emosi sehingga berdampak pada perubahan emosi, sedangkan expressive suppression adalah strategi menghambat keluarnya ekspresi emosi tertentu. Sekalipun kedua strategi ini sangat sering digunakan dalam kehidupan seharihari, namun keduanya memiliki dampak yang berbeda terhadap diri seseorang. Cognitive reappraisal dianggap mampu menumbuhkan pikiran-pikiran positif serta mendorong tercapainya kesejahteraan psikologis. Sedangkan expressive suppression memberikan dampak yang sebaliknya bahkan hingga dapat mengantarkan pada kondisi depresi. Hal ini sejalan dengan studi oleh Cutuli (2014) yang menemukan bahwa strategi cognitive reappraisal diasosiasikan dengan emosi yang lebih sehat, fungsi sosial yang lebih baik, dan lebih sejahtera psikologis daripada strategi expressive suppression.

Panti Asuhan Narayan Seva yang dijadikan sebagai target masyarakat merupakan salah satu panti asuhan yang terletak di Jalan
Raya Kerobokan, Kecamatan Sawan, Kabupaten Buleleng, Bali. Panti asuhan ini menampung sekitar 85 anak yatim piatu. Kegiatan pengabdian ini memfokuskan pada remaja-remaja panti asuhan oleh karena diharapkan mereka dapat menjadi role model bagi adik-adiknya di panti dalam hal mengelola emosi. Secara kemampuan kognitif, remaja sudah mampu menerima konsep-konsep sederhana terkait regulasi emosi dan memiliki rasa ingin tahu yang tinggi (Santrock, 2011). Selain itu, remaja dianggap mengalami lebih banyak emosi negatif daripada tahapan kehidupan lainnya (Mclaughlin, Garrad, \& Somerville, 2015).

Panti Asuhan Narayan Seva memiliki visi mengkomunikasikan pentingnya spiritualitas dan moralitas sebagai fondasi kehidupan manusia. Realisasi diri dan pelayanan kepada kemanusiaan menjadi motto dari panti asuhan ini. Anak-anak asuh di panti ini banyak melakukan beragam aktivitas seperti meditasi, yoga, hingga menanam sayuran dan buah-buahan sebagai sumber bahan makanan untuk seluruh anak-anak panti. Banyak mahasiswa dari dalam maupun luar negeri datang menjadi sukarelawan. Berbagai aktivitas diberikan seperti kursus Bahasa inggris, bermain bersama, membuat kerajinan, dan lainlain. Namun demikian, pendampingan psikologis masih belum banyak dilakukan. Pendampingan psikologis khususnya dalam regulasi emosi penting dilakukan mengingat kondisi saat ini yang rentan menyebabkan seseorang mengalami kendala mental akibat terisolasi dari dunia luar. Kondisi mereka yang tinggal bersama secara komunal di satu tempat secara terus 
menerus menjadi tantangan yang besar dimana satu sama lain diharapkan untuk bisa memiliki sikap toleransi dan kemampuan mengendalikan emosi yang baik agar tidak terjadi konflik atau perpecahan antara satu anak dengan anak lainnya.

Kegiatan pengabdian ini juga menggandeng Bali Kindness, yaitu komunitas yang dikelola oleh anak muda yang memiliki visi untuk menyebarluaskan kebaikan dan nilainilai positif kepada masyarakat melalui kegiatan-kegiatan sosial. Pelaksanaan kegiatan dilakukan dari tanggal 22 Juni hingga 6 Juli 2021. Subyek sasaran pada kegiatan ini adalah remaja Panti Asuhan Narayan Seva yang berada pada rentang usia 16-20 tahun sebanyak 22 orang, yang terdiri dari 17 orang remaja perempuan dan 5 orang remaja laki-laki. Objek sasaran dalam kegiatan ini adalah pelatihan dan pendampingan regulasi emosi. Pelaksanaan kegiatan dilakukan secara langsung atau tatap muka. Beberapa kendala terjadi akibat kondisi pandemi yang kian memburuk, namun tidak mengurangi makna dari pelatihan dan pendampingan yang dilakukan.

\section{METODE}

Metode yang digunakan dalam kegiatan pengabdian ini diantaranya metode ceramah, diskusi, dan unjuk kerja. Dengan menggunakan metode ini, diharapkan suasana pelatihan dan pendampingan lebih interaktif. Terdapat tiga sesi dalam pelaksanaan kegiatan pengabdian ini, diantaranya sesi pelatihan atau pemberian materi, sesi unjuk kerja, kemudian sesi pendampingan. Sebelum kegiatan dimulai, telah dilakukan persiapan diantaranya membuat spanduk, desain, materi pelatihan, hingga menyiapkan instrumen evaluasi. Selanjutnya pada sesi pelatihan, peserta memperoleh materi mengenai teori dan strategi regulasi emosi dari narasumber, berdiskusi, dan berbagi cerita tentang pengalaman mereka dalam mengelola emosi. Pada sesi unjuk kerja, peserta mulai belajar mempraktikkan cara meregulasi emosi yang dipandu oleh narasumber dan beberapa fasilitator. Kemudian pada sesi pendampingan, peserta diberikan kesempatan untuk mengkonsultasikan ide-ide dan pengalaman mereka dalam meregulasi emosi selama kurang lebih satu minggu. Fasilitator memberikan feedback kepada peserta.

Evaluasi kegiatan ini menggunakan metode survey yang dilakukan dengan membagikan kuesioner kepada 22 peserta pelatihan yang merupakan anak asuh di Panti Asuhan Narayan Seva. Terdapat dua jenis kuesioner yang dibagikan, yaitu kuesioner evaluasi program dan kuesioner pengukuran regulasi emosi. Kuesioner evaluasi program hanya diberikan pada akhir dari kegiatan. Pertanyaan yang terdapat di dalam kueisoner seputar tema pelatihan, ketepatan waktu, kelengkapan materi, profesionalisme penyelenggara, penguasaan materi narasumber, cara penyajian materi narasumber, kualitas materi narasumber, serta saran-saran dan masukan untuk penyelenggaraan ke depan. Sedangkan kuesioner pengukuran regulasi emosi diberikan sebelum kegiatan dan setelah kegiatan berakhir. Tujuannya adalah untuk melihat efektivitas dari kegiatan yang diberikan terhadap penggunaan strategi 
regulasi emosi para peserta pelatihan. Instrumen yang digunakan untuk pengukuran regulasi emosi diadaptasi dari Emotion Regulation Questionnaire (ERQ) yang dikembangkan oleh Gross \& John (2003).

Data yang terkumpul dianalisis menggunakan metode deskriptif kuantitatif untuk melihat feedback peserta terhadap kegiatan yang dilakukan serta untuk melihat efektivitas program pelatihan dan pendampingan melalui peningkatan skor pada strategi cognitive reappraisal dan penurunan skor pada strategi expressive suppression.

\section{HASIL DAN PEMBAHASAN}

Pelaksanaan kegiatan pengabdian memiliki tiga tahapan, yaitu sesi pelatihan, sesi unjuk kerja, dan sesi pendampingan. Sebelum semua sesi dimulai, peserta diminta untuk mengerjakan kuesioner pengukuran regulasi emosi untuk melihat kondisi awal sebelum pelatihan dimulai. Pada sesi pelatihan, seluruh peserta menerima materi secara langsung oleh narasumber yang berpengalaman di bidang regulasi emosi. Selama kegiatan pelatihan, suasana sangat interaktif dimana peserta memiliki kesempatan yang besar untuk menjawab, bertanya, dan berbagi pengalaman. Secara umum, peserta tampak antusias mengikuti pelatihan. Hal ini ditunjukkan dengan antusiasme dan keaktifan peserta dalam menjawab pertanyaan dan mengajukan pertanyaan kepada narasumber. Gambar 1 adalah dokumentasi untuk kegiatan pengabdian hari pertama.

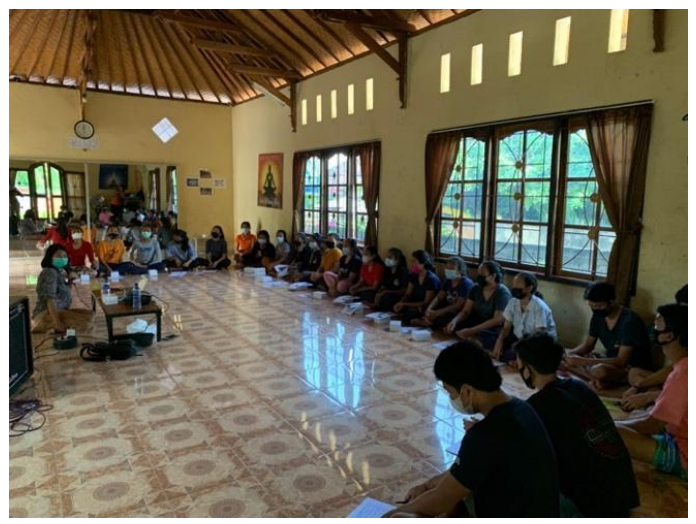

Gambar 1. Pemaparan materi pelatihan dari narasumber

Selain pemaparan materi,
dilakukan juga kegiatan diskusi. Peserta dibagi menjadi beberapa kelompok kecil yang terdiri dari 4-5 orang. Di dalam kelompok kecil, peserta menceritakan permasalahan yang mereka hadapi serta belajar untuk menemukan pikiran alternatif yang positif untuk menumbuhkan emosi yang lebih positif. Di dalam diskusi tersebut, setiap peserta memberikan masukan satu sama lain dan membantu jika ada peserta yang kesulitan menemukan pikiran alternatifnya. Sesi diskusi ini dipandu oleh beberapa panitia yang juga hadir selama kegiatan.

Pada sesi unjuk kerja, peserta mulai belajar untuk mempraktekkan beberapa strategi regulasi emosi yang meliputi afirmasi positif, relaksasi dan latihan pernapasan serta visualisasi. Strategi ini bertujuan untuk membawa pikiran pada hal-hal positif sehingga memunculkan emosi yang positif pula. Gambar 2 merupakan foto peserta melakukan latihan pernapasan dan visualisasi. 


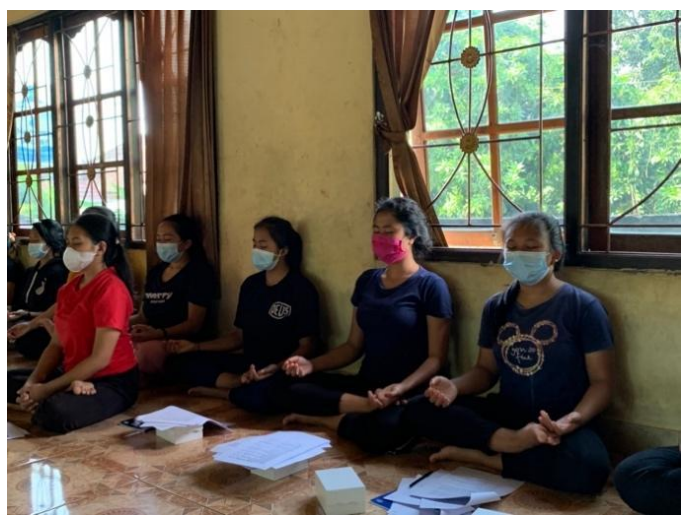

Gambar 2. Peserta mempraktikkan teknik pernapasan dan visualisasi

Pada sesi pendampingan, peserta diberikan lembar kerja yang disebut "Diaryku" untuk menuliskan pengalaman emosional mereka dan mempraktekkan strategi regulasi emosi setiap harinya selama satu minggu. Selama pendampingan, peserta juga diminta untuk menceritakan pengalamannya dan melaporkan permasalahan atau kesulitan yang mereka alami ketika mempraktikkan strategi regulasi emosi. Secara umum peserta mengaku sudah mampu melakukan strategi regulasi emosi secara mandiri walaupun masih ada yang belum sempurna. Proses konsultasi tidak hanya dilakukan secara tatap muka, namun juga melalui metode daring, seperti menggunakan whatsapp chat atau whatsapp call. Gambar 3 merupakan salah satu sesi konsultasi yang diberikan selama pandampingan berlangsung.

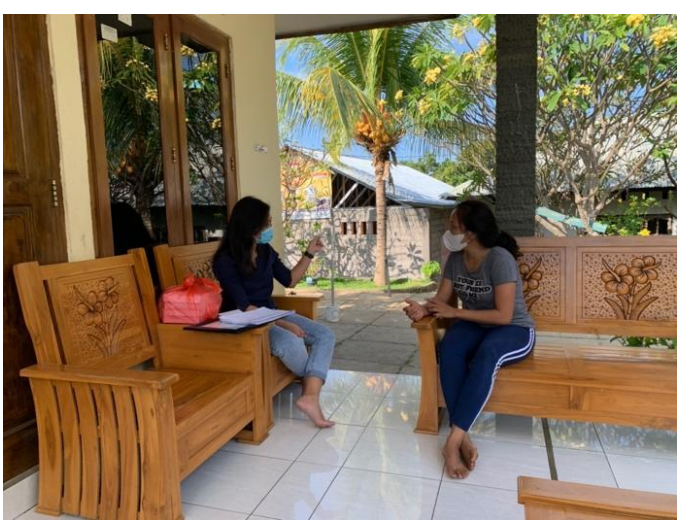

Gambar 3. Peserta menceritakan pengalaman mempraktikkan strategi regulasi emosi

\section{Setelah semua sesi} dilaksanakan, evaluasi tahap akhir dilakukan. Ada tiga jenis data yang dikumpulkan pada angket. Pertama adalah data informasi umum terkait identitas diri, yaitu nama, usia, status pendidikan, dan jenis kelamin. Kedua, data evaluasi program oleh peserta yang meliputi aspek-aspek sebagai berikut: 1) tema pelatihan, 2) ketepatan waktu, 3) kelengkapan materi, 4) profesionalisme penyelenggara, 5) penguasaan materi narasumber, 6) cara penyajian materi narasumber, 7) Interaksi dengan peserta, serta 8) saran-saran dan masukan untuk penyelenggaraan ke depan. Angket yang diberikan berbentuk Skala Likert 1-5 dimana 1 adalah "sangat buruk" dan 5 adalah "sangat baik". Ketiga, data pengukuran regulasi emosi untuk melihat efek pelatihan terhadap peningkatan keterampilan regulasi emosi peserta. Angket yang diberikan berbentuk Skala Likert 1-7 dimana 1 adalah "sangat tidak setuju" dan 7 adalah "sangat setuju". 
Jurnal Widya Laksana, Vol.11, No.1, Januari 2022

Analisis data evaluasi program dilakukan dengan menghitung rata-rata

skor peserta pada setiap aspek. Hasil yang diperoleh adalah sebagai berikut:

Tabel 1. Hasil evaluasi terhadap pelaksanaan program

\begin{tabular}{clc}
\hline No. & Indikator & Skor \\
\hline 1. & Tema Pelatihan & 4,73 \\
2. & Ketepatan Waktu & 4,55 \\
3. & Kelengkapan Materi & 4,73 \\
4. & Profesionalisme penyelenggara & 4,59 \\
5. & Penguasaan Materi & 4,59 \\
6. & Cara Penyajian Materi & 4,77 \\
7. & Interaksi dengan Peserta & 4,64 \\
8. & Kualitas materi yang disajikan & 4,73 \\
& TOTAL & $\mathbf{4 , 6 7}$ \\
\hline
\end{tabular}

Berdasarkan tabel diatas, ratarata skor feedback yang diberikan peserta adalah 4.67. Ini menunjukkan bahwa program "Harmony from Within" dinilai sangat baik oleh peserta. Lebih lanjut peserta merasakan dampak positif dari pelatihan ini seperti misalnya menjadi lebih relaks, menumbuhkan pikiran positif, tenang, lebih mudah berkonsentrasi, serta mengetahui bagaimana cara mengendalikan emosi saat sedang mengalami masalah. Selain itu, saran yang diberikan kepada penyelenggara adalah diharapkan kegiatan serupa dilakukan secara rutin dan dikemas dengan metode yang lebih menarik lagi.

Adapun efektivitas pelatihan dalam meningkatkan strategi regulasi emosi peserta dilihat dari pengukuran menggunakan Emotion Regulation Questionnaire (ERQ) yang disebarkan ke peserta sebelum dan setelah pelatihan. Oleh karena instrumen $\mathrm{ERQ}$ ini melihat dua jenis strategi regulasi emosi, maka pembahasan berikutnya akan dibagi menjadi dua subbab berdasarkan dua strategi tersebut, yaitu cognitive reappraisal dan expressive suppression.

\section{HfW dalam meningkatkan kemampuan merekonstruksi kognitif (cognitive reappraisal)}

Berdasarkan analisis terhadap data dari kuesioner yang dibagikan, diperoleh bahwa terdapat 15 orang (68\%) yang menunjukkan peningkatan dalam kemampuan merekonstruksi pikiran, sedangkan 7 lainnya (32\%) mengalami penurunan. Analisis lebih lanjut dilakukan terhadap hasil latihan peserta yang dituliskan ke dalam lembar Diaryku. Sebagian besar peserta menunjukkan kesungguhan dalam mengerjakan tugas tersebut serta mampu menumbuhkan pikiran alternatif sebagai pengganti pikiran negatif yang menyebabkan munculnya emosi negatif.

Salah satu peserta menuliskan pikiran yang muncul saat mengalami emosi negatif yaitu "Merasa takut dan bimbang saat melakukan sesuatu yang 
belum bisa dilakukan". Kemudian pikiran alternatif yang dimunculkan adalah "Awal permulaan pasti ada kesalahan, tapi harus belajar dari kesalahan itu dan jangan mengulangi kesalahan yang sama”. Perasaan yang muncul setelah merekonstruksi pikiran adalah "Lebih berani dan siap walaupun rasa takut itu belum hilang sepenuhnya". Peserta lainnya juga melaporkan bahwa mereka merasa lebih lega, ringan, lebih bersemangat, serta mampu melihat masalah dari sudut pandang yang lebih positif. Hal ini menunjukkan bahwa usahanya dalam merekonstruksi pikiran dapat melahirkan perasaan dan sikap yang lebih positif dalam melihat situasi. Ini sejalan dengan Larsen, dkk (2012) serta Gross \& John (2003) yang menemukan bahwa seseorang yang menggunakan strategi cognitive reappraisal akan meningkatkan emosi positif. Faktanya, individu yang terbiasa menggunakan cognitive appraisal menunjukkan gejala depresi yang lebih rendah, lebih puas dan optimis, dan memiliki harga diri yang lebih tinggi, tingkat penguasaan lingkungan, pertumbuhan pribadi, penerimaan diri, keterampilan mengatasi, rasa otonomi, serta hubungan interpersonal yang lebih baik (John \& Gross, 2004). Oleh karena itu, penerapan strategi cognitive reappraisal dapat meningkatkan kesejahteraan psikologis secara umum (Kelley, Glazer, Pornpattananangkul, \& Nusslock, 2019).

Walaupun demikian, terdapat 7 orang yang mengalami penurunan pada skor cognitive reappraisal. Hal ini diduga disebabkan oleh kurang optimalnya proses pendampingan yang dilakukan dikarenakan tidak setiap peserta mau menceritakan pikirannya saat sesi pendampingan sehingga tidak semua memperoleh masukan-masukan yang sesuai pada lembar kerja yang diselesaikan oleh peserta.

\section{HfW dalam menurunkan kemampuan menghambat ekspresi emosi (expressive suppression)}

Hasil analisis menunjukkan bahwa 16 orang (73\%) menunjukkan peningkatan dalam kemampuan menghambat ekspresi emosi dan sebanyak 6 orang (27\%) menunjukkan penurunan. Ini menunjukkan bahwa masih banyak peserta yang menggunakan strategi penghambatan ekspresi emosi dalam menyelesaikan masalah. John \& Gross (2003) menyebutkan bahwa seseorang yang melakukan penghambatan ekspresi emosi merasakan penurunan emosi positif serta meningkatkan emosi negatif dengan hadirnya perasaan tidak menjadi diri sendiri. Dalam pengabdian ini, diharapkan peserta mengurangi penggunaan expressive suppression dengan lebih banyak diajarkan mengenai cognitive reappraisal. Namun demikian, hasil yang diperoleh menunjukkan bahwa peserta mengalami peningkatan dalam strategi expressive suppression dan hanya beberapa saja yang mengalami penurunan.

Hasil yang diperoleh tidak sesuai dengan dugaan sebelumnya bahwa diharapkan akan terjadi penurunan strategi expressive suppression setelah diberikan pelatihan dimana peserta diberikan keleluasaan untuk mengekspresikan emosinya. Adapun penjelasan terkait hasil yang tidak sesuai harapan ini adalah adanya 
pengaruh budaya dan nilai-nilai yang dipegang oleh peserta. Matsumoto, Yoo, \& Nakagawa (2008) menemukan bahwa individu dari budaya yang cenderung menekankan pada kohesivitas sosial lebih cenderung menekan reaksi emosional mereka untuk terlebih dahulu mengevaluasi respons apa yang paling sesuai dengan situasi tersebut. Sejalan dengan ini, Lim (2016) menekankan bahwa orang barat lebih sering menunjukkan gairah emosi yang kuat daripada yang lemah, sedangkan pada budaya timur atau kolektivis, gairah emosi yang lemah lebih dihargai dan diterima daripada gairah emosi yang kuat. Penelitian yang dilakukan oleh Handayani, Wirabrata, dan Ambara (2021) menemukan bahwa remaja di Buleleng memiliki toleransi yang tinggi dimana mereka mampu untuk menerima perbedaan yang ada. Hal ini dapat pula berkontribusi pada enggannya remaja untuk mengekspresikan emosinya jika ia tahu bahwa itu akan menyakiti orang lain. Oleh karena itu, peserta diduga menemukan kesulitan dalam menyesuaikan diri untuk mengekspresikan apa yang dirasakan karena tidak sesuai dengan budaya dan nilai-nilai yang dipegangnya.

Selain itu, faktor kedua adalah proses untuk menghilangkan kebiasaan menahan atau menghambat ekspresi emosi tidaklah singkat. Perlu dilakukan latihan berulang kali hingga terbiasa untuk tidak menekan atau menahan ekspresi emosi yang sebenarnya. Walaupun demikian, kemampuan yang baik pada peserta dalam expressive suppression dapat memberikan manfaat khususnya dalam menjaga dinamika sosial antara satu anak dengan anak lainnya. Mereka belajar untuk mengontrol ekspresi emosi mereka sehingga tidak mudah untuk terjadi pertengkaran, kompetisi yang tidak sehat, dan lain-lain.

Secara umum, hasil yang diperoleh dari pelatihan dan pendampingan ini sejalan dengan yang dilakukan oleh Mulyana, Izzati, Budiani, \& Puspitadewi (2020) yang menemukan bahwa kemampuan regulasi emosi meningkat pada remaja setelah mengikuti pelatihan regulasi emosi dan mempraktekkan hasil pelatihan pada saat bertindak atau berinteraksi dengan lingkungan sekitarnya.

\section{KESIMPULAN}

Berdasarkan analisis terhadap hasil kegiatan pelatihan, ditemukan bahwa pelaksanaan kegiatan dinilai sangat baik oleh sebagian besar peserta pelatihan. Selain itu, diperoleh hasil bahwa terjadi peningkatan keterampilan regulasi emosi jenis cognitive reappraisal (merekonstruksi pikiran) serta peningkatan kecenderungan dalam meregulasi emosi menggunakan jenis expressive suppression (menahan ekspresi emosi) pada sebagian besar peserta pelatihan. Hal ini menunjukkan bahwa kegiatan pelatihan "Harmony from Within" ini hanya berhasil dalam meningkatkan keterampilan regulasi emosi dengan merekonstruksi pikiran dan belum berhasil dalam meminimalisir kecenderungan untuk menahan ekspresi emosi.

Adapun rekomendasi yang dapat diberikan untuk kegiatan pengabdian selanjutnya adalah pelatihan regulasi emosi hendaknya 
tidak hanya memfokuskan kegiatan pada strategi merekonstruksi emosi, namun juga memberikan penekanan pada keberanian untuk mengekspresikan emosi, baik itu emosi positif dan negatif. Selain itu, pelatihan dapat dilakukan dengan durasi yang lebih panjang serta kegiatan yang lebih terstruktur agar hasil yang diperoleh lebih maksimal karena keterampilan dalam meningkatkan regulasi emosi membutuhkan proses yang panjang.

\section{DAFTAR PUSTAKA}

Cutuli, D. (2014). Cognitive reappraisal and expressive suppression strategies role in the emotion regulation: an overview on their modulatory effects and neural correlates. Frontiers in Systems Neuroscience, 8(175), 1-6. doi: 10.3389/fnsys.2014.00175.

Gross, J. J. (1998b). The emerging field of emo tion regulation: An integrative review. Review of General Psychology, 2, 271-299.

Gross, J.J., \& John, O.P. (2003). Individual differences in two emotion regulation processes: Implications for affect, relationships, and well-being. Journal of Personality and Social Psychology, 85, 348-362.

Gross, J. J., Richards, J. M., \& John, O. P. (2006). Emotion regulation in everyday life. In D. K. Snyder, J. A. Simpson, \& J. N. Hughes (Eds.), Emotion regulation in couples and families: Pathways to dysfunction and health. Washington, DC: American Psychological Association.
Handayani, D. A. P., Wirabrata, D. G. F., \& Ambara, D. P. (2021). Accept, respect, or appreciate diversity? How diverse educational environment affects tolerance among university students in Buleleng, Bali. Advances in Social Science, Education, and Humanities Research, vol 540. doi: 10.2991/assehr.k.210407.245.

John, O. P., and Gross, J. J. (2004). Healthy and unhealthy emotion regulation: personality processes, individual differences and life span development. J. Pers. 72, 1301-1333. doi: 10.1111/j.14676494.2004.00298.x

Kelley, N. J., Glazer, J. E., Pornpattananangkul, N., \& Nusslock, R. (2019). Reappraisal and suppression emotionregulation tendencies differentially predict rewardresponsivity and psychological well-being. Biological

psychology, 140, 35-47. doi: 10.1016/j.biopsycho.2018.11.005.

Killian, B. \& Durrheim, K. (2008). Psychological distress in orphan, vulnerable and typically developing children in high prevalence HIV/AIDS communities. Journal of Psychology in Africa, 18(3).

Larsen, J. K., Vermulst, A. A., Eisinga, R., English, T., Gross, J. J., Hofman, E., et al. (2012). Social coping by masking? Parental support and peer victimization as mediators of the relationship between depressive symptoms 
Jurnal Widya Laksana, Vol.11, No.1, Januari 2022

and expressive sup- pression in adolescents. J. Youth Adolesc. 41, 1628-1642. doi: 10.1007/s10964-012-9782-7

Lim, N. (2016). Cultural differences in emotion: differences in emotional arousal level between the east and the west. Integr Med Res, 5(2), 105-109.

Matsumoto, D., Yoo, S. H., Nakagawa, S., \& Multinational Study of Cultural Display Rules. (2008). Culture, emotion regulation, and adjustment. Journal of Personality and Social Psychology, 94(6), 925-937. doi: 10.1037/00223514.94.6.925.

McLaughlin, K. A., Hatzenbuehler, M. L., Mennin, D. S., \& NolenHoeksema, S. (2011). Emotion dysregulation and adolescent psychopathology: A prospective study. Behaviour Research and Therapy, 49(9), 544-554.

McLaughlin, K.A., Garrad, M. C. \& Somerville, L. H. (2015). What develops during emotional development? A component process approach to identifying sources of psychopathology risk in adolescence. Dialogues in Clinical Neuroscience, 17(4), 403.
Mulyana, O. P., Izzati, U. A., Budiani, M. S., \& Puspitadewi, W. S. (2020). Pelatihan regulasi emosi untuk meningkatkan strategi regulasi emosi pada mahasiswa Psikologi FIP Unesa yang terdampak Pandemi Covid-19. JURPIKAT (Jurnal Pengabdian kepada Masyarakat, 1(3), 249261.

Pranita, E. (2021, November 29). Kenapa varian baru B.1.1.529 Omicron menular lebih cepat? Kompas.com.

https://www.kompas.com/sains/re $\mathrm{ad} / 2021 / 11 / 29 / 100100523 /$ kenap a-varian-baru-b11529-omicronmenular-lebih-cepat?page=all

Quoidbach, J., Berry, E. V., Hansenne, M., \& Mikolajczak, M. (2010). Positive emotion regulation and well-being: Comparing the impact of eight savoring and dampening strategies. Personality and Individual Differences, 49, 368373.

Santrock, John W. (2011). Life-Span Development $\left(13^{\text {th }}\right.$ ed.). New York: McGraw Hill.

Sinclair, V. G., \& Wallston, K. A. (1999). The development and validation of the psychological vulnerability scale. Cognitive Therapy and Research, 23(2), 119-129 